\title{
Impact of improved beehives technology adoption on honey production efficiency: empirical evidence from Southern Ethiopia
}

\author{
Kassa Tarekegn ${ }^{1 *}$ (i) and Assefa Ayele ${ }^{2}$
}

\begin{abstract}
Background: Kaffa, Sheka and Bench Maji zones of Southern Ethiopia are high honey production areas with dense forest coverage. However, due to the traditional production system, the productivity per hive is low. To exploit this production potential in these zones by increasing productivity per hive, different governmental and non-governmental organizations disseminate improved beehives technologies. Yet, the impact of these disseminated and adopted technologies on honey production has not been determined. Thus, this study aimed to estimate the impact of improved beehive adoption on honey production efficiency.

Methodology: A multistage sampling technique was used to select 360 sampled households. This study applied a stochastic frontier model to assess the technical efficiency (TE) of honey producers and propensity score matching (PSM) with probit model to analyze adoption decision of improved beehive and its impact on honey production efficiency.

Results: The finding of this study shows that the number hives, type of beehive used, and proximity to the available forest had a significant and positive effect on honey production. The mean TE was $77 \%$ that shows the deviation of actual from optimal production amounts. Beekeeping experience, education, level, cooperative membership, participation in improved beehive technology demonstration and extension contact had significant effects on TE. The result of PSM indicates that the adoption of improved beehive technology has a positive and significant effect on production efficiency, as measured by TE. Farmers who adopted improved beehive technology were less technically inefficient than those who did not adopt.

Conclusion: Overall, the estimated 19.5\% difference in TE among the two groups shows there is considerable room for the improvement of beekeeping by efficient utilization of inputs and also provides strong evidence for the diffusion of improved beehives in Kaffa Sheka and Bench Maji zones.
\end{abstract}

Keywords: Adoption, Technical efficiency, Impact, Propensity score match

\section{Background}

Ethiopia is one among the major producers of honey in Africa with its varied ecological and climatic conditions [1]. The country has more than 10 million beehives and

\footnotetext{
${ }^{*}$ Correspondence: kassatar12@gmail.com

${ }^{1}$ Socio-Economics Research Division, Arba Minch Agricultural Research Center (Former Bonga Center), Southern Agricultural Research Institute, P.O. Box 2228, Arba Minch, Ethiopia

Full list of author information is available at the end of the article
}

around 2 million people are involved in honey production [2]. The honey production provides a secondary source of income for smallholder farmers, who traditionally also grow cereals, pulses, oil seeds, and other perennial crops [3]. The country has the potential to produce 500,000 tons of honey, but current production is limited to 43,000 tons of honey [1]. This huge gap is due to the traditional production system in the country which results in low productivity [4]. For instance, $96 \%$ of the hives used in the country are traditional and $91 \%$ of the total honey

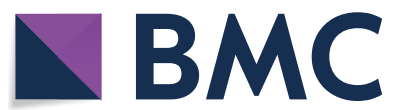

(c) The Author(s) 2020. This article is licensed under a Creative Commons Attribution 4.0 International License, which permits use, sharing, adaptation, distribution and reproduction in any medium or format, as long as you give appropriate credit to the original author(s) and the source, provide a link to the Creative Commons licence, and indicate if changes were made. The images or other third party material in this article are included in the article's Creative Commons licence, unless indicated otherwise in a credit line to the material. If material is not included in the article's Creative Commons licence and your intended use is not permitted by statutory regulation or exceeds the permitted use, you will need to obtain permission directly from the copyright holder. To view a copy of this licence, visit http://creativeco mmons.org/licenses/by/4.0/. The Creative Commons Public Domain Dedication waiver (http://creativecommons.org/publicdomain/ zero/1.0/) applies to the data made available in this article, unless otherwise stated in a credit line to the data. 
produced comes from these hives [5]. The technological improvement is the foremost requirement for increasing agricultural productivity and poverty reduction in the long term [6].

The low productivity of smallholders calls for measures to provide improved technologies to beekeeping farmers to boost honey production and productivity levels. The federal government of Ethiopia has increased its attention by developing national apicultural strategies to assist the poor smallholder farmers by introduction and promotion of improved beehives like Zender, Kenya top bar, Ethioribrab hive, and chefeka ${ }^{1}$ to increase productivity and production of honey $[6,7]$. In line with the federal government, Southern nation nationality people's regional (SNNPR) under its agricultural led development policy gave due attention in selected zones by adopting national apiculture strategies. Of these strategies, introduction and demonstration of different improved apicultural technologies were given priority to increase the volume of honey produced in the region. Among the technologies, improved beehives are the main determinant of honey produced per household [8]. To this effect, different governmental and non-governmental organizations have been involved in demonstrations and dissemination of improved beehive technologies for the last 10 years in the region [9].

Within SNNPR, Kaffa Sheka and Bench Maji zones are the high potential areas for organic honey production with dense forest coverage were given priority as the region [10]. As well, the demand for organic honey that is mostly produced in these zones is currently increasing in domestic and export markets [3]. To exploit the existing production potential and market opportunities, each zonal livestock and fishery development departments in collaboration with federal and regional governments demonstrate and disseminate different improved beekeeping technologies [11]. In addition, different projects like the Agricultural Growth Program (AGP), Apiculture Scale-up Programme for Income and Rural Employment (ASPIRE) and Ethio-Wetlands and Natural Resources Association (EWNRA) involved in the same task. Moreover, different private companies like Sheka Nordic honey development industry and Apinec agro-industry demonstrated by the dissemination of improved box beehives in Sheka and Kaffa zones, respectively [11].

Besides being eco-friendly, beekeeping provides offfarm employment and income-generating opportunity in the study area through organizing jobless urban and landless rural youth and women [12, 13]. Even though

\footnotetext{
${ }^{1}$ Chefeka is a type of improved beehive made from locally available materials by least cost of production.
}

the impact of improved agricultural technologies adoption on productivity and efficiency has been extensively studied in Ethiopia [13-21], most of the studies emphasized on the crop. From the studies, very few have also looked at the impact of livestock technologies adoption. But none of them empirically investigated the impact of improved honey production technologies adoption on honey production efficiency in particular.

Literature shows that the adoption of improved beehives technologies has a positive and significant impact on honey production [7, 22, 23]. This is an incentive for farmers to adopt or continue with the technology because the return to their efforts on investment is realized, that is, increased productivity [22]. Even if an increase in productivity and production is necessary, it is not a sufficient condition to influence all farmers to invest in the adoption of improved technologies given the fact that most of the technologies are expensive [8, 24-27]. Production efficiency is, therefore, one of the economic aspects that may explain the importance of the adoption of improved technologies as inputs of production for a sustainable productive environment [28].

Even though the study areas has high potential for honey production, the efficiency level of beekeepers is $9.8 \mathrm{~kg} / \mathrm{hive} / \mathrm{annum}$, which is still lower than the national average $(12.5 \mathrm{~kg} / \mathrm{hive} /$ annum $)$ from traditional beehives [7]. Therefore, it necessitated the farmers either to use modern technologies or need to use resources efficiently to optimize outputs [29]. Meanwhile, if existing inputs and technologies are not efficiently utilized, trying to introduce new technologies will not be cost-effective [19]. As a result, the use of existing technologies is more cost-effective than applying new technologies. Measuring efficiency level of farmers benefit economies by determining the extent to which it is possible to raise productivity by improving the neglected source of growth (efficiency) with the existing resource base and available technology [30]. Thus, there is a need to understand the extent of production efficiency in terms of technical efficiency and identifying factors that exert influence on honey producer's performance along with technology adoption. The result of such studies will enable policymakers to design and implement effective policies and programs [31]. Hence, the objective of the study was to determine the impact of improved beehives adoption on honey production efficiency of beekeepers in Kaffa Sheka and Bench Maji zones of SNNPR, Ethiopia.

\section{Research methodology}

\section{Description of the study area}

This study was carried out in Kaffa, Sheka and Bench Maji zones (Fig. 1), where a coffee-spice based farming system is dominant. These zones are well known for their dense 


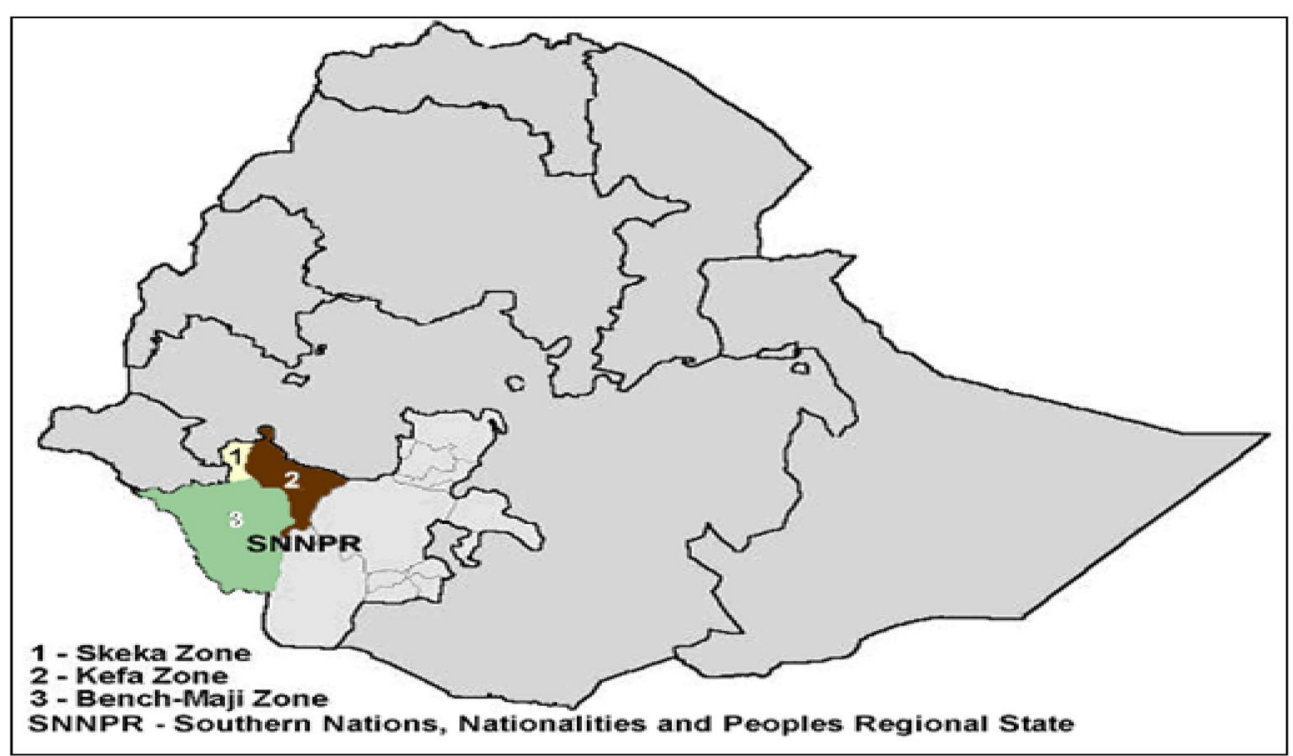

Fig. 1 Map of study area

forest resources and high potential of honey, coffee and spice production [32]. The estimated total area of Kaffa, Sheka and Bench Maji zones is about $32,702.73 \mathrm{~km}^{2}$, which is about $30.9 \%$ of the total area of the region [5]. The three zones have a well-distributed sufficient rainfall, with only a short period of a dry spell, as well as a warm to hot temperature. The annual mean temperature of the zones ranges from 10.1 to $27.5^{\circ} \mathrm{C}$, whereas the average annual rainfall varies between 400 to $2200 \mathrm{~mm}$ [33].

\section{Sampling techniques}

For this study, a multistage sampling technique was applied to select a total of 360 sampled households. In the first stage, six districts namely Gesha and Chena districts from the Kaffa zone; Masha and Anderacha districts from the Sheka zone and Sheko and Debubi Benchi districts from the Benchi Maji zone were selected purposively considering their honey production. In the second stage, a total of 12 rural kebeles (the lowest administrative unit in Ethiopia) were selected from the six districts. From the selected kebeles, the households were stratified and listed into honey producers and non-producers. Finally, from the producers' group each kebeles, 30 honey producing households were selected using a simple random sampling technique. The intended data were collected using a structured questionnaire that was administered by trained enumerators.

\section{Analytical methods \\ The probit model}

Adoption decision studies mostly employ a probit/logit model to determine the factors that influence the probability [24]. In this study, adoption of improved beehive is considered as intervention determinant for impact evaluation. Thus, in the regression of propensity scores, logit and probit are standard approaches for estimating models with limited dependent variables. Both approaches produce similar results when estimating the probability of an individual farmer being an adopter ${ }^{2}$ or a non-adopter [34]. In this paper, we use the Probit model to estimate propensity scores due to its basic assumptions of the error term (normal distribution) [35]. Probit model takes a value 1 and 0 that are assigned to represent the choice whether a farmer decides to adopt or not. The standard probit model that assesses the household adoption decision is described as follows:

$$
\begin{aligned}
& D_{i}=\alpha^{\prime} Z_{i}+V_{i} \text { (adoption decisions equation) } \\
& D_{i}=1, \text { if } D_{i} *>0 \text { and } 0 \text { if } D_{i} * \leq 0,
\end{aligned}
$$

where $D_{i}$ is a dummy variable that takes the value 1 if the farmer adopts improved box hive and zero otherwise, $Z$ is a vector of independent variables hypothesized to affect households decision to adopt the technology) and

\footnotetext{
${ }^{2}$ Adopters are those beekeepers who used minimum of three improved box hives for at least for 2 years and non-adopters are beekeepers who did not use improved box hives during the study period.
} 
$\alpha$ is a vector of parameter to be estimated and $V_{i}$ error term.

\section{Stochastic frontier model (SF)}

To measure the impact of improved beehives adoption on honey production efficiency, we considered the technical efficiency (TE) of farmers as our outcome variable. TE refers to the ability of a decision-making unit (DMU) to produce the maximum feasible output from a given bundle of inputs [36, 37]. Any deviation from this maximal output is considered as technical inefficiency [38]. TE can be measured by using either parametric or non-parametric approaches. The main difference between the two approaches is that the non-parametric approach assumes that the DMU has full control over the production process and all deviations from the frontier are associated with inefficiency. The parametric approach on the other hand distinguishes inefficiency from deviations that are caused by factors beyond the control of the DMU [39].

This study used the stochastic frontier approach (SFA) to estimate TE. This approach has been preferred over the non-parametric data envelopment analysis (DEA) since it uses the method of maximum likelihood that gives more robust results as opposed to DEA which relies on mathematical programming [29, 37]. Furthermore, honey production has inherent variability due to random shocks and available data on production are likely to be subject to measurement errors [13]. These errors and random shocks result variation in honey output as result the stochastic production frontier was used for its key features that the disturbance term is composed of two parts, a symmetric and a one-sided component [40].

Therefore, the stochastic frontier model developed independently by Aigner et al. [41] was adopted for this cross-sectional data. Thus, the model was specified as follows:

$$
\ln (y)=x_{i} \beta+v_{i}-\mu_{i}, \quad i=1,2, \ldots N \quad v \sim N(0, \sigma 2 v),
$$

where $-y_{i}$ represents the logarithm of the output of the $i$ th productive unit, $x_{i}$ is a vector of inputs, $\beta$ is the vector of technology parameters, $v_{i}$, representing measurement and specification error, $\mu_{i}$, representing inefficiency. Moreover, $v_{i}$ and $\mu_{i}$ are assumed to be independent of each other and independently and identically distributed across observations [37].

Different functional forms represent the production frontier. The two commonly used functional forms are Cobb-Douglas and Translog, each having their merits and demerits. Both models overwhelmingly dominate the application literature in stochastic frontier and econometric inefficiency estimation [38]. However, based on a hypothesis test result in this study Cobb-Douglas production function was estimated. The dependent variable in the production function is the total honey produced by the household during the $2017 / 2018$ production season. The explanatory variables used in the production function are the number of hives $(\mathrm{NoH})$, proximity to available natural forest (Frst), bee forage utilization (BeeFor), labor (Labr), a supplement used (Suplmt) and improved hives utilization (ImpH). Thus, Cobb-Douglas frontier function is specified as follows:

$$
\begin{aligned}
\ln (\text { OUTP })= & \beta_{0}+\beta_{1} \ln \mathrm{NoH}+\beta_{2} \ln \text { Frst }+\beta_{3} \ln \operatorname{lneeFor} \\
& +\beta_{4} \operatorname{lnLabr}+\beta_{5} \ln \text { Suplmt }+\beta_{6} \ln \mathrm{Imp} B H \\
& +v_{i}-u_{i},
\end{aligned}
$$

where $v_{i}$-is the disturbance error term, independently and identically distributed as $N\left(0, \sigma_{v}^{2}\right)$ intended to capture events beyond the control of farmers; and $\mu_{i}$ is a non-negative random variable, independently and identically distributed as $N\left(\mu, \sigma_{\mu}^{2}\right)$ intended to capture technical inefficiency effects in the production of honey measured as the ratio of observed output to maximum feasible output of the $i$ th household.

The exogenous variables expected to influence on the TE of producers includes sex of household (sex), household size (hsize), experience of household (exp), education status (edu), cooperative membership (coop), distance to market (dist), participations in demonstration (demsrt), extension contact (exten) and household income (income). By these exogenous variables, the inefficiency score $\left(\mu_{i}\right)$ is formulated based on the assumption of half-normal distribution with mean $\mu_{i}$ and $\sigma^{2}$. Thus, the inefficiency score is specified as follows:

$$
\begin{aligned}
\mu_{i}= & \delta_{0}+\delta_{1} \text { sex }+\delta_{2} \text { hsize }+\delta_{3} \exp +\delta_{4} \text { edu } \\
& +\delta_{5} \text { coop }+\delta_{6} \text { dist }+\delta_{7} \text { demstr } \\
& +\delta_{8} \text { exten }+\delta_{9} \text { income }+w_{i}
\end{aligned}
$$

where $\mu_{i}$ is the inefficiency score of the $i$ th household; $\delta_{i}$ is a vector of parameter to be estimated; $w_{i}$ is the error term.

\section{Propensity score matching (PSM) techniques}

To estimate the impact of improved beehive technology adoption on production efficiency, the PSM technique was utilized for this study. PSM uses information from a pool of units that do not adopt the intervention to identify what would have happened to adopting units in the absence of the intervention [42]. By comparing how outcomes differ for adopters relative to observationally similar non-adopters, it is possible to estimate the effects of the intervention [43].

This technique helps to adjust for initial differences between a cross section of adopters and non-adopters 
by matching each unit based on similar observable characteristics [44]. An important assumption on which this technique builds is the conditional independence assumption (CIA), which states that selection is solely based on observable characteristics and potential outcomes are independent of treatment assignment [42]. Besides the CIA, another condition in PSM is the common support requirement, which ensures that individuals compared from the two groups are, to begin with, comparable. Specifically, it ensures individuals with the same observable characteristics have a positive probability of being in both groups [45]. This requirement can be imposed such that estimation is performed on individuals that have common support. The average treatment effect on the treated (ATT) is therefore, given by the difference in mean outcome of matched adopters and non-adopters that have common support conditional on the propensity score [46].

The PSM also allows for examination of the probability of adoption in addition to assessing the effect of adoption on technical efficiency $[43,47,48]$. The average treatment effect (ATE) is estimated as the mean difference in technical efficiency between adopters, denoted by $Y(1)$ and matched control group, denoted by $Y(0)$ :

$$
\mathrm{ATE}=E[Y(1)-Y(0)]=E[Y(1)]-E[Y(0)] .
$$

The ATE compares the technical efficiency of farmers who adopted the technology with that of non-adopters or control farmers that are similar in terms of observable characteristics and also partially control for non-random selection of adopters in the improved beehive technology adoption. The ATT measures the effect of adoption on the technical efficiency of farmers who adopted only the improved beehive technologies rather than across all farmers who potentially could have adopted these technologies. ATT is calculated as follows:

$$
\begin{gathered}
\mathrm{ATT}=E[Y(1)-Y(0) \| G=1]=E[Y(1) \| G=1] \\
-E[Y(0) \| G=1 .
\end{gathered}
$$

There is no way to get adopters with the same score as its counterfactual(s) since the propensity score is a continuous variable. Thus, there is a need to search for counterfactual(s) that match with each adopter depending on its propensity score. To do this, different matching (Caliper, Kernel, and Nearest Neighbor) algorithms were used to match and test the robustness of the differences in ATT among the groups in the common support region based on balancing tests [49]. If balancing test results indicated no significant $(p<0.05)$ differences in mean $P$-scores for adopter and non-adopter groups, implying that the adopters and non-adopters are likely to have similar characteristics and fall in the region of common support [50]. For above all, the variables hypothesized to be used in SF and PSM analysis were appended in Appendix Table 7.

\section{Results and discussion}

\section{Determinants of adoption decision of improved box} beehive

This section presents the results of the probit regression model which is used to estimate propensity scores for matching TE of adopted households with non-adopters. The model sufficiently fitted the data at $1 \%$ significance level $\left(\operatorname{LR} \chi^{2}(12)=44.47 ;\right.$ Prob $\left.>\chi^{2}=0.00\right)$. The result shown in Table 1 indicates that the household income had a positive and significant effect on adoption. The positive relationship implies that the decision to adopt improved beehive technology depends on income to purchase it. The founding of the result is consistent with Asmiro et al. [26].

Beekeepers' residence distance from farmer training center (FTC) had a significant and negative influence on adoption. The implication of this may be due to those beekeepers who reside far apart from FTC have relatively less probability to get information about the advantages of improved hive technology than their counter-parts. The result concurs with the findings of Asmiro et al. [26]. There was a positive and significant relationship between the frequency of extension service and the adoption of improved beehive technologies. The farmers who are frequently visited by extension agents tended to be more progressive and more likely to adopt improved hive technology. The result is consistent with Kirtti et al. [27], Tadele [25], and Olusegun et al. [24].

Table 1 Determinants of adoption decision from PSM (probit model result)

\begin{tabular}{lcl}
\hline Independent variables & Coefficient & Standard error \\
\hline Sex of household head & 0.0492 & 0.0308 \\
Education level household head & 0.0348 & 0.0481 \\
Household size & -0.0290 & 0.0301 \\
Total annual income (1000) & $0.120^{* *}$ & 0.0539 \\
Beekeeping experience & -0.0919 & 0.0590 \\
Distance from FTC & $-0.1870^{*}$ & 0.1079 \\
Extension contact & $0.1891^{*}$ & 0.1121 \\
Credit utilization & 0.1035 & 0.1025 \\
Perception of high price (high) & $-0.8891^{* * *}$ & 0.3630 \\
Perception of high price (medium) & $-0.3155^{* *}$ & 0.1430 \\
Cooperative membership & 0.1373 & 0.1286 \\
Number of local beehives owned & 0.0145 & 0.0117 \\
Constant & 0.2460 & 0.2050 \\
\hline
\end{tabular}

***, ** and ${ }^{*}$ denote significance at the 1,5 and $10 \%$, respectively 
Table 2 Generalized likelihood ratio tests of hypothesis for the parameters of the SPF. Source: own computation from the survey data (2018)

\begin{tabular}{|c|c|c|c|c|c|c|}
\hline Null hypothesis & DF & $\mathrm{LH}_{0}$ & $\mathrm{LH}_{1}$ & $\begin{array}{l}\text { Calculated } x^{2}(\mathrm{LR}) \\
\text { value }\end{array}$ & $\begin{array}{l}\text { Critical value }\left(x^{2},\right. \\
0.01)\end{array}$ & Decision \\
\hline Ho: $\beta_{8}=\beta_{9} \ldots=\beta_{35}=0$ & 28 & 34.33 & 50.45 & 32.24 & 48.27 & Not reject \\
\hline $\mathrm{H}_{0}: u_{i}=\delta_{1}=\delta_{2}=\ldots=\delta_{9}=0$ & 9 & -7.22 & 33.67 & 81.78 & 21.66 & Reject \\
\hline
\end{tabular}

Participation in the demonstration of improved beehive technology had a positive effect on the decision to adopt it and significant at $1 \%$. This may be due to that beekeepers who participate in demonstrations of improved beehive technology get the chance to exchanges knowledge and experience which motivates them towards adopting the technology. This result finding coincides with Abdulai and Abubakari [51], Workneh [52], and Tamrat [53]. Finally, farmer's relative perception on the price of improved beehives affects the adoption decision negatively at a $1 \%$ level of significance. The regression result confirms that the farmers who perceive the price of improved beehive is high and medium, the adoption probability is relatively low as compared to those farmers who perceive the price as low. This is may-be due to lack of knowledge in terms of yield advantage of improved beehive and only considering the relatively low price with tradition beehive. Study by Merga and Urgessa [54] and Yiyi et al. [55] found a similar result.

\section{Technical efficiency analysis}

\section{Stochastic production frontier (SPF) estimation}

To estimate the impact of improved beehives on honey production efficiency, this study considered the technical efficiency of honey producers as a proxy variable. Thus, to discuss about parameter estimates of SPF (production frontier function and the inefficiency effects), it is advisable to run hypotheses tests to choose an appropriate model for further analysis and interpretation [55]. Tests of hypothesis for the parameters of the frontier model are conducted using the generalized likelihood ratio statistics, $\lambda$, defined as:

$$
l=-2\left[\log L\left(H_{O}\right)-\log L\left(H_{1}\right)\right] .
$$

The generalized likelihood ratio test found the CobbDouglas form appropriate for the stochastic frontier analysis (Table 2). The null hypothesis that the socioeconomic variables did not explain the presence of technical inefficiency was also rejected in this study.

\section{Determinants of honey production}

Table 3 indicates that the significant determinants of honey production were the number of hives owns, type of beehives used, and proximity of natural forest. All the inputs exhibited positive coefficients (elasticities of production) implying that they have a positive effect on output. The regression result shows that increasing number of beehives by $1 \%$ is likely to increase honey production by $0.145 \%(p<0.01)$ ceteris paribus, while the decreasing in proximity to natural forest by $1 \%$ is likely to increase production by $0.139 \%(p<0.05)$ ceteris paribus (Table 3). Among the inputs, the utilization of improved beehive as the technology the major input to increase honey production in the study area. The regression result confirms that volume honey production per household increase by $0.488 \%$ for improved beehive technology users as compared to non-users holding other factors constant. Labor however had no significant influence on honey output. The insignificance of labor to honey yield could be attributed to the direct relationship between the quantity of labor used and the number of beehives owned.

Table 3 Maximum likelihood estimates of stochastic frontier model

\begin{tabular}{lccc}
\hline Input variables & Coefficients & Std. & $\boldsymbol{p}$ value \\
\hline Constant & $0.674^{* *}$ & 0.146 & 0.000 \\
Number hive (In) & $0.145^{* * *}$ & 0.028 & 0.000 \\
Lab our use in (man-day) (In) & 0.042 & 0.057 & 0.468 \\
Type of beehive used & $0.488^{* * *}$ & 0.071 & 0.000 \\
Bee forage cultivation (In) & 0.077 & 0.048 & 0.106 \\
Proximity to natural forest & $-0.139^{* *}$ & 0.037 & 0.000 \\
Supplement used (In) & 0.004 & 0.025 & 0.880 \\
Inefficiency variables & & & \\
Constant & -1.049 & 1.329 & 0.809 \\
Sex household head (Hh) & 0.741 & 0.536 & 0.345 \\
Household size & 0.106 & 0.066 & 0.109 \\
Beekeeping experience of Hh & $0.153^{*}$ & 0.085 & 0.071 \\
Education level of Hh & $-0.081^{* * *}$ & 0.025 & 0.002 \\
Cooperative member & $-2.856^{* * *}$ & 0.470 & 0.000 \\
Distance to market & 1.305 & 0.585 & 0.126 \\
Participations in demonstration & $-1.684^{* * *}$ & 0.496 & 0.001 \\
Extension contact per year & $-0.042^{* *}$ & 0.019 & 0.034 \\
Total income (In) & 0.236 & 0.441 & 0.592 \\
Sigma square & $0.153^{* * *}$ & & 0.002 \\
Gamma & $0.435^{* *}$ & & 0.032 \\
Log likelihood & -213.888 & & \\
\hline
\end{tabular}

***,** and * denote significant at the 1,5 and $10 \%$, respectively 


\section{Determinants of technical inefficiency}

The diagnostic statistics of the inefficiency component in Table 3 reveal that sigma squared $\left(\sigma^{2}\right)$ was statistically significant indicating goodness of fit, and the correctness of the distributional form assumed for the composite error term. The estimated value of Gamma $(\gamma)$ is 0.435 which indicates that $43.5 \%$ of the total variation in honey output among sample farmers is due to technical inefficiency.

The regression result also showed that there are several factors that influence honey production efficiency. Among the factors, TE has a significant relationship with beekeeping experience $(p<0.1)$, education $(p<0.01)$, cooperative membership $(p<0.01)$, participation on improved beehive technology demonstration $(p<0.01)$ and extension contact $(p<0.05)$ (Table 3$)$.

With regard to individual significant factors, beekeeping experience has an inverse relationship with TE. This indicates that a household that had long experience in beekeeping tends to be less technically efficient. This may be related to the experience associated with a traditional hive and traditional ways of production. As a result, households with long beekeeping experience may be reluctant to accept recently distributed new technology. Other studies have also shown that TE is significantly affected by the beekeeping experience of the households. For instance, Eman et al. [56] reported that the experience of the farmer was a significant determinant of TE of white honey producers in Saud, while cooperative membership has a positive relationship with TE which indicates that member of cooperative had a significantly higher $(2.856 \%)$ TE than those who were not a member. This means that honey producers who are the member of honey cooperatives are more efficient than other non-members. The study by Abdulai and Abubakari [57] in Ghana confirms that membership of group determines the efficiency of honey producers.

Participation in demonstrations of improved beehive technologies influences the efficiency level of honey producers positively. The regression result indicates honey producers who participated in demonstrations of improved beekeeping technologies are more efficient (1.68\%) than their counterparts. This is probably because households who have access could get the technical knowledge and skills needed to produce honey more efficiently. In addition, extension contact with regard to honey production have a positive effect on TE of honey producers. This could indicate the effectiveness of the extension service shows improvement in the apiculture sector. Shifrawu and Gebremickael [13] found a similar result that confirms participation in demonstrations and getting extension contact frequently improves the efficiency of honey producers in Ethiopia. As well, Kuboja et al. [23] also found that visits by beekeeping extension
Table 4 Technical efficiency (TE) scores. Source: own computation from survey data (2018)

\begin{tabular}{llllll}
\hline Variable & Observations & Mean & Std. dev. & min & Max \\
\hline Te (combined) & 360 & 0.77 & 0.15 & 0.25 & 0.96 \\
Te (adopters) & 201 & 0.89 & 0.10 & 0.47 & 0.96 \\
Te (non-adopters) & 159 & 0.65 & 0.20 & 0.25 & 0.81 \\
\hline
\end{tabular}

officers and access to beekeeping training are the main factors that significantly enhanced the economic efficiency of small-scale beekeepers in Tabora and Katavi regions, Tanzania.

\section{Average technical efficiency scores of honey production}

Before estimating impact, production efficiency in terms of TE should be estimated first to predict mean TE of each of the household which is used as an outcome variable for impact evaluation. Table 4 presents the analyzed result of TE among adopters and non-adopters of improved beehive technology. The estimated TE for the sampled households ranged from 0.25 to 0.96 with a standard deviation of 0.15 . The mean TE estimates for adopters and non-adopters were 0.89 and 0.65 , respectively, with overall mean technical efficiency of 0.77 . This result shows that farmers can increase their honey production by $23 \%$ which is lost due to the technical inefficiency. This result corroborates earlier findings that show farmers do not attain maximum efficiency. For instance, Olarinde et al. [58] found out that the mean TE for beekeeping farms in Oyo State, Nigeria was $85.4 \%$. Another study, Kuboja et al. [23] reported that the mean economic efficiency of beekeepers in Tabora and Katavi regions, Tanzania was 92\%, while Affognon et al. [22] reported that the mean TE for honey production in the former Mwingi District of Kenya was 56\%.

\section{Impact of improved beehives technology adoption on honey producers' $\mathrm{TE}$}

This subsection presents the results from the PSM techniques of impact estimation. The distribution of the households for the estimated propensity scores shows that most of them are found on partly the middle and partly in the right side of the distribution that in case of treatment households. On the other hand, most of the control households are partly found in the center and partly in the left side of the distribution (Fig. 2)

\section{Matching adopters and non-adopter households}

Before implementing the matching task for the predicted values of propensity scores, a common support condition should be imposed on the propensity score distributions of households with and without the technology adoption. 


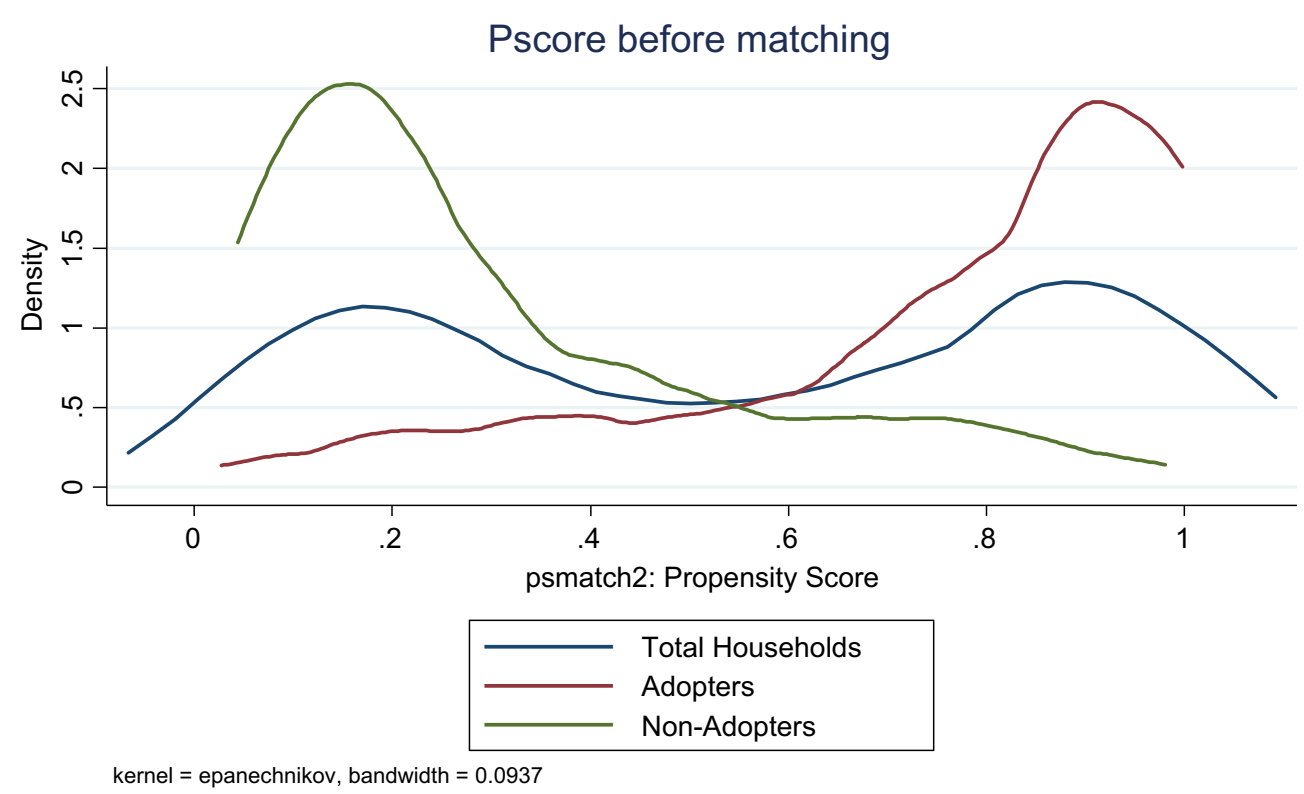

Fig. 2 Kernel density of propensity scores of all households before matching

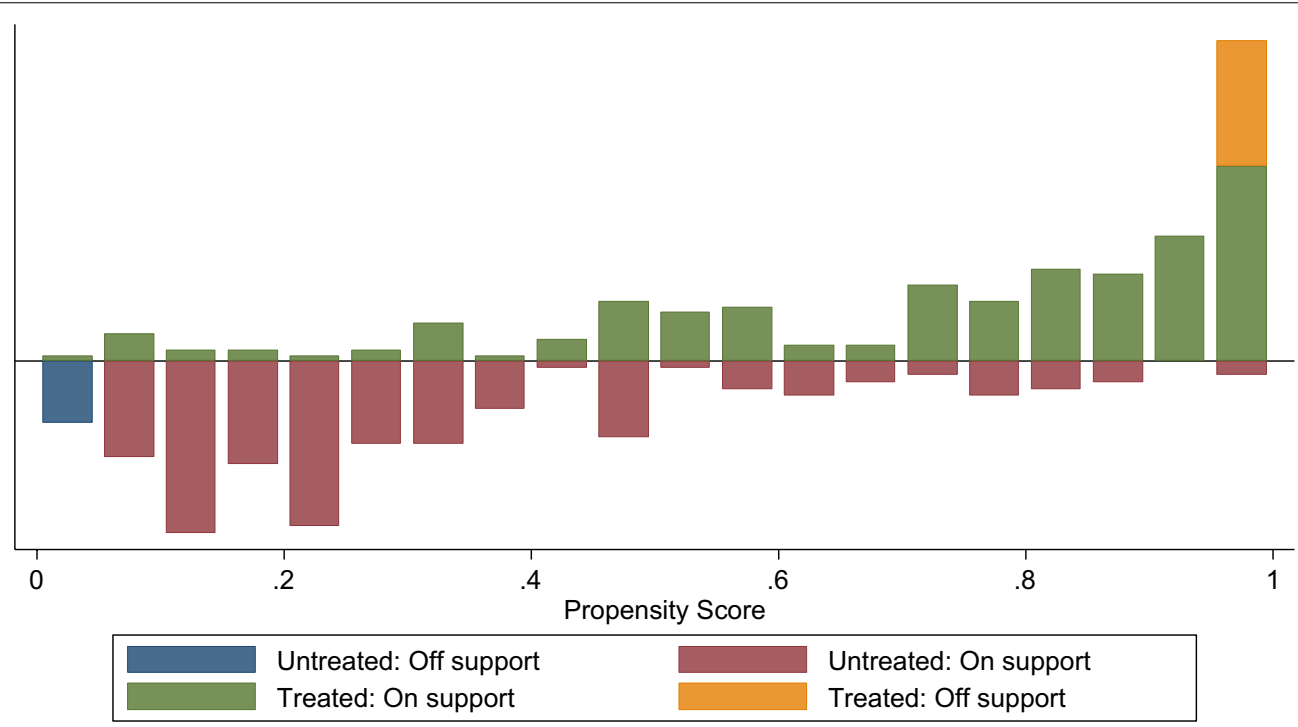

Fig. 3 The distribution of propensity scores for treated and untreated groups

From the distributional graph (Fig. 3), the off support (the observations whose predicted propensity scores fall outside the range of the common support region) should be discarded.

The estimated propensity scores vary between 0.248 and 0.987 with a mean of 0.819 for treatment households and between 0.088 and 0.895 with a mean of 0.544 for control households (Table 5). The common support
Table 5 Distribution of sample households by estimated propensity scores and household type

\begin{tabular}{llllll}
\hline Variable & Obsrv & Mean & St. dev & Min & Max \\
\hline Adoption & 201 & 0.819 & 0.244 & 0.248 & 0.987 \\
Non-adoption & 159 & 0.544 & 0.253 & 0.088 & 0.895 \\
Total households & 360 & 0.738 & 0.247 & 0.088 & 0.987 \\
\hline
\end{tabular}




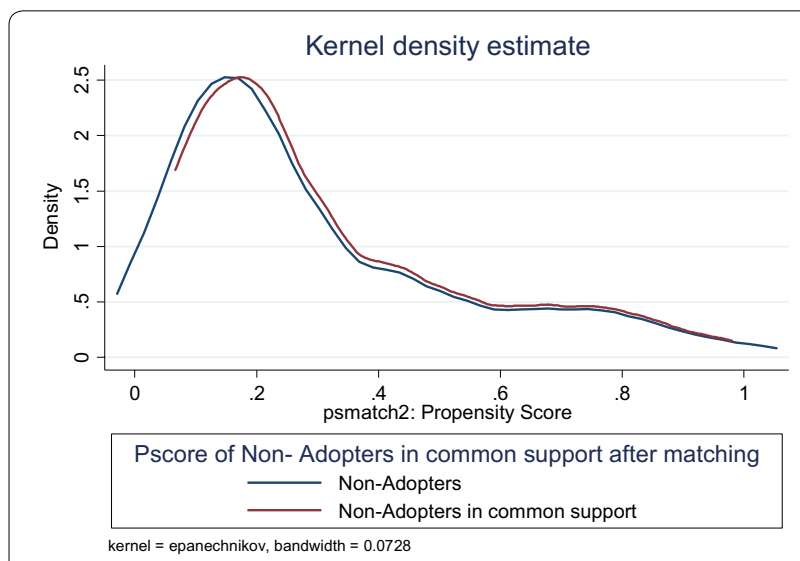

Fig. 4 Kernel density for non-adopters Pscore after matching

region would be then between 0.248 and 0.895 that is the minimum and the maximum value of treated and control households, respectively. This ensures that any combination of characteristics observed in the treatment group can also be observed among the control group. In other words, households whose estimated propensity scores are less than 0.248 and larger than 0.895 are not considered for matching exercise. This is because no matches can be made to estimate the average treatment effects on the ATT parameter when there is no overlap between the treatment and non-treatment group. As a result of this restriction, 21 households from treated and 12 households from the control were discarded.

\section{Choice of matching algorithm}

The effect of adoption on TE was estimated using four matching estimators, as none were a priori superior to the others [49]. This study adopted the matching estimator selected based on the criteria by Deheia and Wahba [59]. A matching estimator having balanced mean bears a low pseudo- $R^{2}$ value and also the one that results in a large matched sample size is preferred. Accordingly, radius matching and kernel matching provided better matching indicating a good level of covariate balancing (Appendix Table 8). However, this study employs a radius matching algorithm, which uses all of the comparison units within a pre-determined radius. The advantage of this method is that it uses as many comparison units available within the radius, thus allowing for the use of extra units when good matches are not available [60]. In addition, the quality of matching can also be assessed by visual inspection using graphs (Figs. 4 and 5). The distributions of the estimated propensity scores were somehow skewed to the right for adopter households and to the left for non-adopter households.

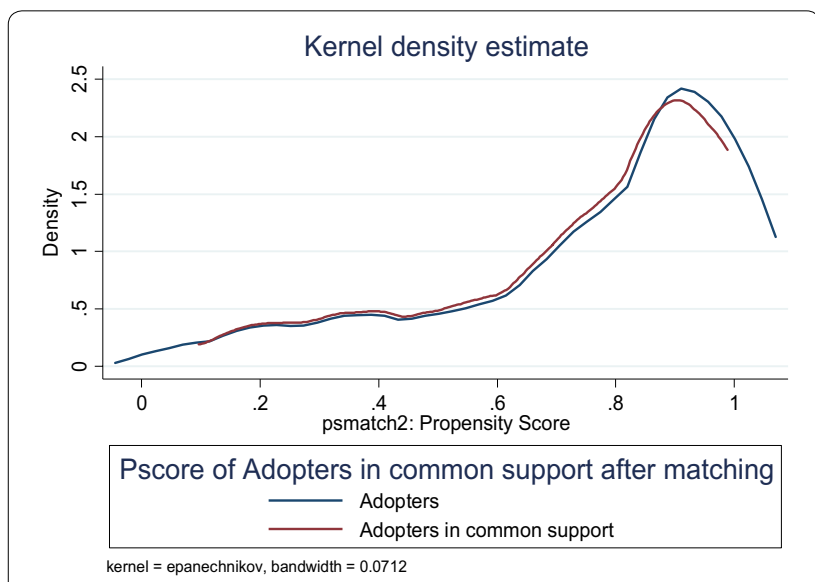

Fig. 5 Kernel density for adopters Pscore after matching

Table 6 Estimated the average treatment effect on the treated group (ATT) in the study area

\begin{tabular}{lllllc}
\hline Outcome variables & Treated & Control & Diff & SE & $T$-value \\
\hline Unmatched TE & 0.90715 & 0.72713 & 0.18003 & 0.01135 & 15.86 \\
ATT after matching TE & 0.89619 & 0.70111 & 0.19495 & 0.06745 & 2.89 \\
\hline
\end{tabular}

The estimated results show supportive evidence of statistically significant impact of improved beehive adoption on honey production efficiency. The finding of this study revealed that the mean difference in TE between the two groups of sample households is significant at $1 \%$ probability level. The average treatment effect on the treated (ATT), the statistic of interest, shows a significant difference in TE between the adopters and non-adopters (Table 6). The average honey production efficiency gain due to adoption was approximately $19.5 \%$ and this indicates that adoption had a strong positive and significant effect on honey production. A study by Merga and Urgessa [54]; Affognon et al. [22] and Nicholaus [61] also confirm that the adoption of the improved beehive has a positive and significant impact on honey production.

\section{Conclusion}

This study analyzed the impact of improved beehive adoption on honey production efficiency southwestern zones of SNNPR, Ethiopia, and provided more evidence of inefficiency in honey production due to the gap in the allocation of resources and adoption of the improved technology. Participation in demonstration of improved beehive technology, household income and extension contact had a positive effect on adoption decision, while perception on the price of improved beehive and distance from FTC had a negative effect. 
The stochastic frontier regression result also indicates that the number of hives with improved type and proximity to natural forest are important significant determinants among the inputs in honey production. The study findings have also shown that the TE for the pooled sample was 0.77 , implying that there is a room to improve efficiency by 0.23 . Furthermore, the results show that adopters had higher mean TE (0.89) than their non-adopter counterparts (0.65). The interventions such as providing training to farmers on practices that increase beehive productivity through adoption of yield-enhancing technologies such as the use of improved beehive, bee forage development and conservation of available forest.

The result obtained from the propensity score also shows that the adopters of improved beehive more efficient by $19.5 \%$ as compared to counterparts. Thus, the introduction and demonstrations of improved beehives with the recommended technologies is the only option available to exploit the potential and to increase honey production. Overall, there is a great room to improve the efficiency level of honey producers by reallocating inputs. Since the adoption of improved beehive technology has multiplier effects ranging from beekeeping productivity growth to economic growth and poverty reduction, the findings of the study stress the need for appropriate policy implementation which improves the adoption of productivity enhancing technologies in general and improved beehive in particular. Thus, we recommend that policies should be formulated to take advantage of the factors influencing farmer's adoption of improved beehive technology. In addition, efforts should be made to increase access to improved beehives by introducing substitutes that can be constructed from locally available material and reduce production cost like chefeka.

\section{Abbreviations}

CSA: Central Statistical Agency of Ethiopia; MOA: Ministry of Agriculture; SNNPR: Southern Nation Nationality Peoples Region; AGP: Agricultural Growth Program; ASPIRE: Apiculture Scale-up Programme for Income and Rural Employment; EWNRA: Ethio-Wetlands and Natural Resources Association; FTC: Farmers Training Center; TE: Technical efficiency; DMU: Decision-making unit; SPF: Stochastic production frontier; DEA: Data envelopment analysis; PSM: Propensity score matching; CIA: Conditional independence assumption; ATT: Average treatment effect on the treated; ATE: Average treatment effect.

\section{Acknowledgements}

The authors would like to thank the experts of livestock and fishery office from sampled districts for their cooperation and sampled honey producers for providing necessary information. We gratefully acknowledge Southern Agricultural Research Institute (SARI) for their financial support. Finally, we would like to thank the two reviewers for their constructive comments.

\section{Authors' contributions}

KT contributed in research proposal writing, data collection, data analysis, data interpretation and article writing. AA contributed in additional interpretation of result. Both authors read and approved the final manuscript.

\section{Funding}

This study was funded by Southern Agricultural Research Institute (SARI), Ethiopia.

Availability of data and materials

The datasets are used and/or analyzed during the current study available from the corresponding author on request.

Ethics approval and consent to participate

Not applicable.

\section{Consent for publication}

Not applicable.

\section{Competing interests}

We declare that we do not have competing interests.

\section{Author details}

${ }^{1}$ Socio-Economics Research Division, Arba Minch Agricultural Research Center (Former Bonga Center), Southern Agricultural Research Institute, P.O. Box 2228, Arba Minch, Ethiopia. ${ }^{2}$ Department of Agricultural Economics and Agribusiness Management, College of Agriculture and Veterinary Medicine, Jimma University, P.O. Box 307, Jimma, Ethiopia.

\section{Appendix}

See Tables 7, 8. 
Table 7 Hypothesized variables definitions and measurements

\begin{tabular}{|c|c|c|c|}
\hline Variables & Type & Measurements & Effect \\
\hline Adoption of improved beehives technology (D) & Dummy & $1=$ Adopter, $0=$ non-adopter & \\
\hline Number of improved beehives owned (year) & Continuous & Number & + \\
\hline Sex of household head & Dummy & $1=$ Male, $0=$ female & + \\
\hline Educational level of household head & Continuous & Grade & + \\
\hline Household size & Continuous & Man equivalent & + \\
\hline Total income in 1000 & Continuous & ETB & + \\
\hline Beekeeping experience & Continuous & Year & - \\
\hline Number of local beehive owned & Continuous & Number & - \\
\hline Participation in demonstration of improved hives & Dummy & $1=$ Yes, $0=$ No & + \\
\hline Perception towards price of improved beehives & Categorical & $1=$ high, $2=$ medium, $3=$ low & - \\
\hline Frequency of extension contact per year & Continuous & Number & + \\
\hline Distance from farmers training center & Continuous & Kilometer/minute & + \\
\hline Cooperative membership & Dummy & $1=$ yes $1,0=$ No & + \\
\hline Credit utilization & Dummy & $1=$ user, $0=$ non-user & + \\
\hline Type of beehive used & Dummy & $1=\mid$ mproved, $0=$ traditional & + \\
\hline Proximity to natural forest & Dummy & $1=$ yes $0=$ no & + \\
\hline Bee forage cultivation & Continuous & Timad & + \\
\hline Supplement used (sugar) & Continuous & $\mathrm{Kg}$ & + \\
\hline
\end{tabular}

\section{Table 8 Matching algorithms}

\begin{tabular}{llll}
\hline $\begin{array}{l}\text { Matching } \\
\text { algorithm }\end{array}$ & Balancing test & Pseudo $\boldsymbol{R}^{\mathbf{2}}$ & Sample size \\
\hline Kernel & & & \\
0.01 & 7 & 0.4895 & 260 \\
0.1 & 9 & 0.4895 & 327 \\
0.25 & 9 & 0.4895 & 327 \\
0.5 & 8 & 0.4895 & 327 \\
Caliper & & & \\
0.01 & 8 & 0.4895 & 260 \\
0.1 & 6 & 0.4895 & 265 \\
0.25 & 6 & 0.4895 & 265 \\
0.5 & 5 & 0.4895 & 265 \\
Neighbor & & & \\
1 & 8 & 0.4895 & 265 \\
2 & 7 & 0.4895 & 265 \\
3 & 7 & 0.4895 & 265 \\
4 & 6 & 0.4895 & 265 \\
5 & 6 & 0.4895 & 265 \\
Radius caliper & & & \\
0.01 & 5 & 0.4895 & 327 \\
0.1 & 9 & 0.4895 & 360 \\
0.25 & 9 & 0.4895 & \\
0.5 & 8 & 0.4895 & \\
\hline
\end{tabular}

Italic values represent the significant matching algorithms
Received: 27 December 2019 Accepted: 17 May 2020

Published online: 20 July 2020

\section{References}

1. FAOSTAT (Food and Agriculture Organization of the United Nations) FAOSTAT database. 2015. http://data.fao.org/ref/262b79ca-279c-451793de-ee3b7c7cb553.

2. Shekhar A, Gizachew S. Engaging smallholders in value chains: creating new opportunities for beekeepers in Ethiopia, programme insights. Nairobi: Oxfam GB; 2011.

3. Gallmann P, Thomas H. Beekeeping and honey production in southwestern Ethiopia. 2012. http://www.learningforlife.ch/media/DIR_76001 176253729aa011222ffff8015a426365.pdf.

4. Kenesa T. Status of beekeeping in Ethiopia. J Dairy Vet Sci. 2018;8(4):1-12.

5. CSA (Central Statistical Agency). Survey 2014/15 (2007 E.C.) Volume II report of livestock characteristics (private peasant holdings) Ababa, Ethiopia; 2015.

6. MoA, ILRI. Apiculture value chain vision and strategy for Ethiopia. Addis Ababa: Ministry of Agriculture and International Livestock Research Institute; 2013.

7. Awraris G, Yemisarach G, Degane A, Nuri A, Gebayo G, Workine A. Honey production systems (Apis mellifera L.) in Kafa, Sheka and Bench-Maji zones of Ethiopia. J Agric Ext Rural Dev. 2012;4(19):528-41.

8. Fikru S. Review of honey bee and honey production in Ethiopia. J Anim Sci Adv. 2015:5(10):1413-21.

9. SNNPRBA (Southern Nations, Nationalities and People Regional State's Bureau of Agriculture). Livestock resource extension annual plan cooperative agreement, SNNPR, Ethiopia; 2015

10. Awraris G, Amenay A, Hailemariam G, Nuru A, Dejen A, Zerihun T, Asrat T. Comparative analysis of colony performance and profit from different beehive types in Southwest Ethiopia. Glob J Anim Sci Res. 2015;3(1):178-85. 
11. Kassa T, Gonche G, Amenay A. Value chain analysis of honey in Kaffa and Sheka Zones of SNNPR, Ethiopia. Int J Res Agric Sci. 2017;4(3):142-8.

12. Ajabush D. Review of economical and ecological importance of bee and bee products in Ethiopia. J Anim Husb Dairy Sci. 2018;2(2):18-26.

13. Shiferaw K, Gebremedhin B. Technical efficiency of small-scale honey producers in Ethiopia: a stochastic frontier analysis. In: LIVES Working Paper 20. Nairobi, Kenya: International Livestock Research Institute; 2016.

14. Tesfaye S, Bedada B, Mesay Y. Impact of improved wheat technology adoption on productivity and income in Ethiopia. Afr Crop Sci J. 2016;24(s1):127-35

15. Teklewold H, Kassie M, Shiferaw B, Köhlin G. Cropping system diversification, conservation tillage and modern seed adoption in Ethiopia: impacts on household income, agrochemical use and demand for labor. Ecol Econ. 2013;93:85-93.

16. Mulat $\mathrm{G}$. The impact of technology adoption on agricultural productivity and production risk in Ethiopia: evidence from Rural Amhara household survey. Open Access Libr J. 2016;3:23-39.

17. Musa HA, Hiwot MM, Seltene A, Wendmagegn M, Amare K. Adoption of improved groundnut seed and its impact on rural households' welfare in Eastern Ethiopia. Cogent Econ Finan. 2016:4:1-13.

18. Musa HA, Kassahun MG, Aemro T, Eden A. The impact of improved maize varieties on farm productivity and wellbeing: evidence from the East Hararghe Zone of Ethiopia. Dev Stud Res. 2017;4(1):9-21.

19. Abro ZA, Debela BL, Kassie M. The joint impact of improved maize seeds on productivity and efficiency: implications for policy. Global Food Discussion Paper 128, University of Gottingen; 2019.

20. Tesfaye H, Baye B, Eyob B, Kaleb K, Daniel H, Fitsum D. Impact of improved wheat variety on productivity in Oromia Region, Ethiopia. Greener J Agric Sci. 2018;8(4):74-81.

21. Agerie NW, Tigabu DK, Abebe DK. Analysis of technical efficiency of potato (Solanum tuberosum L.) production in Chilga District, Amhara National Regional State, Ethiopia. Econ Struct. 2019;8(34):1-18.

22. Affognon HD, Kingori WS, Omondi Al, Diiro MG, Muriithi BW, Makau S, Raina SK. Adoption of modern beekeeping and its impact on honey production in the former Mwingi District of Kenya: assessment using theory-based impact evaluation approach. Int J Trop Insect Sci. 2015;35(2):96-102.

23. Kuboja N, Isinika A, Kilima F. Determinants of economic efficiency among small-scale beekeepers in Tabora and Katavi regions, Tanzania: a stochastic profit frontier approach. Dev Stud Res. 2017:4(1):1-8.

24. Olusegun A, Dare A, Begho T. Factors influencing adoption decisions of maize farmers in Nigeria. Int J Food Agric Econ. 2014;2(3):45-54.

25. Tadele $\mathrm{AH}$. Factors affecting adoption of modern beehive in Saese Tsaeda District of Tigray Ethiopia. J Energy Technol Policy. 2016;6(2):29-36.

26. Asmiro A, Kindye A, Mulugeta A, Lijalem A. Adoption and Intensity of Modern Bee Hive in wag Himra and North Wollo zones, Amhara region, Ethiopia. Agric Resour Econ Int Sci E-J. 2017;3(1):5-26.

27. Kirtti RP, Phanindra G. Impact of farmer education on farm productivity under varying technologies: case of paddy growers in India. Agric Food Econ. 2018;6(7):1-19.

28. Selejio O, Razack B, John K. Smallholder agricultural production efficiency of adopters and non-adopters of land conservation technologies in Tanzania. J Environ Dev. 2018; 0(0):1-27.

29. Daniel MO, Jackline B, Basil M. Farm level allocative efficiency of rice production in Gulu and Amuru districts, Northern Uganda. Agric Food Econ. 2019;7(19):1-19.

30. Asfaw S, Shiferaw B, Simtowe F, Lipper L. Impact of modern agricultural technologies on smallholder welfare: evidence from Tanzania and Ethiopia. Food Policy. 2012;37(3):283-95.

31. Wubneshe D, Manfred Z, Tim K. The impact of agricultural technologies on poverty and vulnerability of smallholders in Ethiopia: a panel data analysis. Soc Indic Res. 2020;147:517-44.

32. Abdu M, Melkamu B, Mohammed A. Smallholder commercialization and commercial farming in coffee-spice based farming systems: the case of Kaffa, Sheka and Bench Maji Zones. Ethiopian Institute of Agricultural Research; Research report, Addis Ababa Ethiopia; 2016.

33. SNNNPRSIEMP (Southern Nations Nationalities Regional State Investment Expansion Main Process). Regional investment strategy, Hawassa Ethiopia; 2011.
34. Geta E, Bogale A, Kassa B, Elias E. Productivity and efficiency analysis of smallholder maize producers in southern Ethiopia. J Hum Ecol. 2013:41(1):67-74.

35. Greene WH. Econometric analysis (7th (International) ed.). New York University. Pearson 978-0-273-75356-8 ISBN 13; 2012

36. Farrell M. The measurement of productive efficiency. J R Stat Soc Ser A. 1957;120(3):253-90.

37. Kumbhakar SC, Wang HJ, Horncastle AP. A practitioner's guide to stochastic frontier analysis using stata. New York: Cambridge University Press; 2015.

38. Coelli TJ, Rao DSP, O'Donnell CJ, Battese GE. An introduction to efficiency and productivity analysis. 2nd ed. New York: Springer; 2005.

39. Ahmed MH, Melesse KA. Impact of off-farm activities on technical efficiency: evidence from maize producers of eastern Ethiopia. Agric Food Econ. 2018;6(3):1-15.

40. Tim C, George B. Identification of factors which influence the technical inefficiency of Indian farmers. Austria J Agric Econ. 1996;40(2):103-28.

41. Aigner DJ, Knox LC, Schmidt P. Formulation and estimation of stochastic agricultural models. J Econometr. 1977;6:21-37.

42. Rosenbaum PR, Rubin DB. Constructing a control group using multivariate matched sampling methods that incorporate the propensity score. Am Stat. 1983;39:33-8.

43. Benjamin TA. Are adopters of improved rice varieties more productive than non-adopters? Empirical evidence from Northern Ghana. Ghana J Dev Stud. 2019;16(1):92-107.

44. Mariapia M. Agricultural technology adoption and poverty reduction: a propensity-score matching analysis for rural Bangladesh. Food Policy. 2007;32:372-93.

45. Leuven E, Sianesi B. PSMATCH2: Stata module to perform propensity score matching, common support graphing, and covariate imbalance testing. 2003. http://ideas.repec.org.html.

46. Tommaso N. Simulation-based sensitivity analysis for matching estimators. Stata J. 2007:7(3):334-50.

47. Haitao Wu, Ding Shijun, Pandey Sushil, Tao Dayun. Assessing the impact of agricultural technology adoption on farmers' well-being using propensity-score matching analysis in rural China. Asian Econ J. 2010;24(2):141-60.

48. Becker SO, Ichino A. Estimation of average treatment effects based on propensity scores. Stata J. 2002;2:358-77.

49. Nichols A. Causal inference with observational data. Stata J. 2007;7(4):507-41.

50. Heckman JJ, Ichimura $\mathrm{H}$, Todd PE. Matching as an econometric evaluation estimator: evidence from evaluating a job training programme. Rev Econ Stud. 1997:4:605-54.

51. Workneh AW. Financial benefits of box hive and the determinants of its adoption in selected district of Ethiopia. Am J Econ. 2011;1 (1):21-9.

52. Tamrat G. Adoption of modern bee hive in Arsi Zone of Oromia Region: determinants and financial benefits. Agric Sci. 2015;6:382-96.

53. Merga C, Urgessa T. Determinants and impacts of modern agricultural technology adoption in West Wollega: the case of Gulliso District. J Biol Agric Healthc. 2014;4(20):63-7.

54. Yiyi D, Kwadwo F, Robel H, Min L, Anna M.S, Lucas VC. Improving household livelihoods with modern beekeeping and honey production in Ethiopia. Final report for WEEMA International. 2016. https://www.googl e.com/url;BWEEMA\%2BInternational.pdf.

55. Belotti F, Daidone S, Ilardi G, Atella V. Stochastic frontier analysis using StataStochastic frontier analysis using Stata. Stata J. 2013;13(4):719-58.

56. Eman T, Noha E, Mohamad A. Economics of technical efficiency in white honey production: using stochastic frontier production function. Saudi J Biol Sci. 2019:26(7):1478-84.

57. Abdulai AM, Abubakari M. Technical efficiency of beekeeping farmers in Tolon-Kumbungu district of Northern region of Ghana. J Dev Agric Econ. 2012:4(11):304-10.

58. Olarinde LO, Ajao AO, Okunola SO. Determinants of technical efficiency in bee-keeping farms in Oyo State, Nigeria: a stochastic production frontier approach. Res J Agric Biol Sci. 2008;4(1):65-9.

59. Dehejia RH, Wahba S. Propensity score matching methods for non-experimental causal studies. Rev Econ Stat. 2002;84(1):151-61.

60. Abdulaziz S, Shaufique FS. A propensity score matching analysis of the impact of participation in non-farm enterprise activities on household wellbeing in rural Nigeria. UMK Procedia. 2014;1:26-32. 
61. Nicholaus MK. Economic efficiency of beekeeping and its implications on household income among beekeepers in Tabora and Katavi Regions, Tanzania. Doctoral Dissertation, Sokoine Univeristy of Agriculture, Morogoro, Tanzania; 2017

\section{Publisher's Note}

Springer Nature remains neutral with regard to jurisdictional claims in published maps and institutional affiliations.
Ready to submit your research? Choose BMC and benefit from:

- fast, convenient online submission

- thorough peer review by experienced researchers in your field

- rapid publication on acceptance

- support for research data, including large and complex data types

- gold Open Access which fosters wider collaboration and increased citations

- maximum visibility for your research: over 100M website views per year

At BMC, research is always in progress.

Learn more biomedcentral.com/submissions 